Validitas Tes Diagnostik Cepat untuk Screening Malaria di Puskesmas Harapan Kabupaten Jayapura

\title{
Validity of Rapid Diagnostic Test for Malaria Screening at Puskesmas Harapan Jayapura Regency
}

\author{
Zusana Lena Tulak \\ Balai Teknik Kesehatan Lingkungan dan Pengendalian Penyakit Kelas II Ambon \\ (zusantulak@ymail.com, 082193148388)
}

\begin{abstract}
ABSTRAK
Malaria merupakan penyakit infeksi yang disebabkan oleh lima jenis Plasmodium dan dapat menyebabkan kematian. Seorang penderita malaria harus dapat didiagnosa dengan tepat jenis plasmodium yang menginfeksi agar tepat pengobatannya, dan dapat terhindar dari kematian. Uji Validitas RDT Malaria dilakukan di Kabupaten Sentani Jayapura Provinsi Papua, digunakan dalam mendiagnosis malaria di daerah tersebut. Penelitian ini bertujuan untuk mengetahui spesifisitas dan sensitivitas RDT Malaria yang digunakan di Puskesmas Harapan Kabupaten Jayapura dibandingkan dengan gold standard (mikroskopis). Penelitian ini merupakan survei deskriptif yang menggambarkan secara faktual tentang kualitas dari RDT yang digunakan. Alat dan bahan yang digunakan yaitu RDT malaria, slide, mikroskop dan bahan penunjang pemeriksaan mikroskopis malaria lainnya. Sampel yang digunakan adalah darah jari dari pengunjung puskesmas yang memiliki gejala klinis malaria. Hasil uji menunjukkan bahwa dari 19 sampel yang diperiksa terdapat 4 sampel positif benar (RDT dan mikroskopis), dan 14 sampel negatif benar (RDT dan mikroskopis), dan 1 sampel terbaca invalid pada RDT, namun pada pemeriksaan mikroskopis terbaca negatif. Dari hasil pembacaan tersebut diperoleh nilai sensitivitas dan spesifisitas sebesar 100\%. Kesimpulan dari kegiatan ini adalah RDT masih efektif untuk digunakan sebagai alat diagnostik malaria yang dapat mendeteksi secara cepat dan akurat, terutama di daerah endemis tinggi seperti Papua.
\end{abstract}

Kata Kunci: Malaria, validitas RDT, spesifisitas, sensitivitas

\section{ABSTRACT}

Malaria is an infectious disease caused by five types of Plasmodium and can cause death. Type of plasmodium that is infecting a malaria patient, should be diagnosis exactly in order to treat it properly, and can avoid death. This Malaria RDT iin Sentani Jayapura Regency, Papua Province, which is used in diagnosing malaria in the area. The aims of this study is to determine the specificity and sensitivity of the malaria RDT that used at the Harapan Public Health Center in Jayapura Regency compared to the gold standard (microscopic). This study is an survey descriptive study that describes factually the quality of the used RDT. The tools and materials used were the malaria RDT, slides, microscopes and other supporting materials for malaria microscopic examination. The sample used was finger blood from public health care visitors who had clinical symptoms of malaria. The test results showed that of the 19 samples examined there were 4 true positive samples (RDT and microscopic), and 13 true negative samples (RDT and microscopic), and 2 samples read invalid on RDT, but on microscopic examination it read negative. From the results of these readings, the sensitivity and specificity values were obtained at 100\%. The conclusion of this activity is that RDT is still effective as a malaria diagnostic tool that can detect it quickly and accurately, especially in high endemic areas such as Papua.

Keywords: Malaria, RDT validity, spesificity, sensitivity

Article Info:

Received: 30 April 2021 | Revised form: 15 Juni 2021 |Accepted: 19 Juni 2021 |Published online: 30 Juni 2021 


\section{PENDAHULUAN}

Malaria merupakan salah satu masalah kesehatan masyarakat yang dapat menyebabkan kematian terutama pada kelempok berisiko tinggi yaitu bayi, balita dan ibu hamil. ${ }^{1}$ Selain itu malaria secara langsung dapat menyebabkan anemia dan dapat menurunkan produktivitas kerja. Penyakit ini juga masih endemis di sebagian besar wilayah Indonesia. Angka kesakitan penyakit ini pun masih cukup tinggi, terutama di daerah Indonesia bagian timur. ${ }^{2}$

Di Indonesia penderita malaria mencapai 1-2 juta orang pertahun, dengan angka kematian sebanyak 100 ribu jiwa. Angka kesakitan malaria secara nasional selama tahun 2009-2018 cenderung menurun yaitu dari 1,8 per 1.000 penduduk pada tahun 2009 menjadi 0,84 per 1.000 penduduk pada tahun 2018 , dan mengalami sedikit peningkatan di tahun 2019 yaitu 0,93 per 1000 penduduk. Kasus tertinggi penyakit malaria adalah daerah Papua.

Data kasus malaria di Provinsi Papua menunjukkan jumlah suspek PCD di 29 wilayah Kab/Kota tahun 2019 sebanyak 588.981 dengan jumlah positif terdeteksi malaria melalui penggunaan RDT sebanyak 27.579 jiwa. Provinsi Papua merupakan salah satu provinsi yang belum memiliki satu-pun kabupaten yang telah masuk dalam kategori eliminasi malaria. ${ }^{3}$ Sedangkan data kasus malaria di Kabupaten Jayapura menunjukkan bahwa dalam 3 tahun terakhir (2016-2018) jumlah kasus malaria yang terdeteksi sebanyak 66.330 dimana terjadi penurunan jumlah kasus dari 25.078 tahun 2016 menjadi 22.309 tahun 2017 dan 18.943 di tahun $2018 .^{4}$
Pada tahun 2019 jumlah penderita terkonfirmasi meningkat lagi menjadi 21.742 orang dari total penduduk sebanyak 131.802 jiwa. ${ }^{5}$ Meskipun begitu, Provinsi Papua masih merupakan daerah dengan malaria tertinggi dibandingkan dengan wilayah lainnya di Indonesia sehingga upaya percepatan eliminasi malaria di wilayah Papua dan Papua Barat harus dilakukan melalui kualitas pelayanan laboratorium malaria yang merupakan komponen kunci pengendalian malaria dalam menegakkan diagnosis dan tentunya sangat bergantung pada kompetensi dan kinerja petugas. ${ }^{6}$ Kabupaten Jayapura memiliki 24 tenaga mikroskopis terlatih untuk pemeriksaan malaria, dengan 19 diantaranya memiliki kompetensi yang memenuhi syarat untuk pemeriksaan mikroskopis malaria. $^{7}$

Diagnosa malaria yang awalnya bisa dilakukan dengan hanya pemeriksaan gejala klinis saja. Namun, hal ini tidak diperkenankan lagi. Sehingga sekarang digunakan cara yang lebih cepat dan akurat. Pemeriksaan tersebut ialah Rapid Diagnostic Test atau RDT. Walaupun demikian, pemakaian RDT sebagai alat pemeriksaan alternative malaria sangat perlu dievaluasi secara berkala. Penurunan sensitivitas RDT yang terdeteksi dini dapat mengurangi terjadinya false negative khususnya di daerah endemis.

Kegiatan survei ini bertujuan untuk membandingkan efektivitas RDT Malaria dengan pemeriksaan mikroskopik (gold standard) pada pasien yang datang dengan gejala klinis malaria di Puskesmas Harapan Kabupaten Jayapura. 


\section{BAHAN DAN METODE}

Jenis metode penelitian survei deskriptif dan menggunakan rancangan uji diagnostik untuk mendapatkan nilai sensitivitas dan spesifisitas dengan membandingkan hasil pemeriksaan malaria dengan menggunakan RDT dan mikroskopis. Survei dilakukan pada tanggal 12 s.d. 16 Februari tahun 2020 di puskesmas Harapan Kabupaten Jayapura. Populasi adalah semua pasien yang berkunjung di Puskesmas Harapan pada tanggal 13-14 Februari 2020, sebanyak 62 orang. Sampel adalah mereka yang memeriksakan diri di Puskesmas dengan gejala klinis malaria, sebanyak 19 orang. Teknik sampling adalah purposive sampling.

Data dikumpulkan dengan form/instrument yang telah disediakan sebelumnya yang memuat tentang identitas diri, hasil pemeriksaan dengan RDT, serta hasil pemeriksaan dengan mikroskop. Peralatan dan bahan yang digunakan antara lain RDT malaria, slide, bahan pengecatan slide, sediaan darah jari (tebal dan tipis) serta mikroskop. Data dianalisa secara deskripif dan disajikan dalam bentuk tabel dan narasi.

\section{HASIL}

Survei dalam dua hari menemukan 19 orang pasien yang datang dengan keluhan klinis malaria (Tabel 1). Dari mereka diambil sediaan darah jari untuk apusan tipis dan tebal (pemeriksaan mikroskopis) dan untuk pemeriksaan dengan menggunakan uji diagnostik cepat (RDT). Pada hasil pemeriksaan dengan RDT, ditemukan 4 yang positif malaria, 14 negatif dan 1 invalid. Sedangkan pada hasil pemeriksaan dengan menggunakan mikroskop, ditemukan 4 yang positif malaria, dan 15 negatif.

Tabel 1. Perbandingan Hasil Pemeriksaan RDT dan Mikroskopik

\begin{tabular}{crr}
\hline Jenis Pemeriksaan & n & \% \\
\hline Pemeriksaan RDT & 4 & 21,05 \\
Positif & 13 & 68,42 \\
Negatif & 2 & 10,53 \\
Invalid & & \\
Pemeriksaan & & \\
Mikroskopik & 4 & 21,05 \\
Positif & 15 & 78,95 \\
Negatif & $\mathbf{1 9}$ & $\mathbf{1 0 0 , 0 0}$ \\
\hline Total & &
\end{tabular}

Tabel 2. Karakteristik Responden Survei Uji Validitas RDT

\begin{tabular}{crr}
\hline $\begin{array}{c}\text { Karakteristik } \\
\text { Responden }\end{array}$ & n & \% \\
\hline Umur & & \\
0-15 Tahun & 8 & 42,1 \\
$>15$ Tahun & 11 & 57,9 \\
\hline Jenis Kelamin & & \\
Laki-laki & 7 & 36,8 \\
Perempuan & 12 & 63,2 \\
\hline Total & $\mathbf{1 9}$ & $\mathbf{1 0 0 , 0 0}$ \\
\hline
\end{tabular}

Sumber : Data primer, 2020

Dari 19 pasien yang didiagnosa, 8 diantaranya berusia 0-15 tahun, 11 lainnya berusia $>15$ Tahun. Sedangkan berdasarkan jenis kelamin, ada 7 orang laki-laki dan 12 perempuan (Tabel 2). Dan berdasarkan hasil pemeriksaan dengan menggunakan RDT, ada 4 orang yang positif berusia 0-15 tahun, dan 14 orang yang negatif berusia $>15$ tahun. Sedangkan menurut jenis kelamin, ada 3 orang yang positif berjenis kelamin laki-laki, serta 1 orang perempuan dari 14 orang yang negatif, 4 orang diantaranya berjenis kelamin laki-laki, dan 10 lainnya berjenis kelamin perempuan (Tabel 3). 
Tabel 4, 5, 6 dan 7 memperlihatkan perbandingan hasil pemeriksaan RDT dan mikroskopis, perhitungan nilai sensitivitas dan spesifisitas dari RDT Malaria yang digunakan di Puskesmas Harapan Kabupaten Jayapura, serta akurasi spesies. Pada Tabel 4 dapat diketahui bahwa hasil pemeriksaan RDT sama dengan hasil pemeriksaan mikroskopis, dimana $4(22,2 \%)$ hasil positif pada RDT sama dengan hasil pemeriksaan mikroskopis. Hal yang sama juga terjadi pada hasil negatif, yaitu sebanyak $14(77,8 \%)$ orang. Pada Tabel 5 dapat dilihat secara lebih terperinci setiap hasil pemeriksaan baik hasil pemeriksaan mikroskopis maupun pemeriksaan RDT. Pada sampel nomor 01, pembacaan mikroskopis menunjukkan positif vivax ++ , cocok dengan pembacaan RDT yaitu Pos PAN atau positif $P$. Vivax. Pada sampel nomor 04, pembacaan RDT menunjukkan infeksi $P$. Mix, namun pembacaan mikroskop menunjukkan hanya infeksi $P$. Falciparum ++++. Hal serupa terjadi pada pasien dengan nomor sampel 11. Menurut keterangan dari pengelola program malaria Puskesmas Harapan (berdasarkan pengalaman) bahwa apabila terdapat jumlah parasit yang banyak di dalam sediaan darah/infeksi malaria tropika $(P$. Falciparum) sudah berlangsung lama, maka hasil pemeriksaan yang ditunjukkan RDT adalah positif Mix. Pada pasien dengan nomor sampel 18, hasil pemeriksaan cocok antara RDT dan mikroskopis yaitu positif falciparum (positif 1). Berdasarkan perbandingan hasil pemeriksaan tersebut, dilakukan perhitungan nilai sensitivitas dan spesifisitas yang dapat dilihat pada Tabel 6. Dalam tabel tersebut diketahui nilai sensitivitas dan spesifisitas RDT Malaria yang digunakan di Puskesmas Harapan Kabupaten Jayapura, yaitu 100\%. Sedangkan pada Tabel 7 ditunjukkan tentang akurasi spesies menurut hasil pemeriksaan RDT yang hanya $50 \%$.

Tabel 3. Hasil Pemeriksaan RDT Berdasarkan Karakteristik Responden

\begin{tabular}{|c|c|c|c|c|c|c|}
\hline \multirow{3}{*}{ Variabel } & \multicolumn{6}{|c|}{ Hasil Pemeriksaan RDT } \\
\hline & \multicolumn{2}{|c|}{ Positif } & \multicolumn{2}{|c|}{ Negatif } & \multicolumn{2}{|c|}{ Total } \\
\hline & $\mathbf{n}$ & $(\%)$ & $\mathbf{n}$ & $(\%)$ & $\mathbf{N}$ & $(\%)$ \\
\hline \multicolumn{7}{|l|}{ Umur } \\
\hline 0-15 Tahun & 4 & 22,2 & 4 & 22,2 & 8 & 44,4 \\
\hline$>15$ Tahun & 0 & 0,0 & 10 & 55,6 & 10 & 55,6 \\
\hline \multicolumn{7}{|l|}{ Jenis Kelamin } \\
\hline Laki-Laki & 3 & 16,7 & 4 & 22,2 & 7 & 38,9 \\
\hline Perempuan & 1 & 5,6 & 10 & 55,6 & 11 & 61,1 \\
\hline
\end{tabular}

Sumber : Data Primer, 2020 
Tabel 4. Perbandingan Hasil Pemeriksaan RDT dengan Pemeriksaan Mikroskopik

\begin{tabular}{lrrrrrr}
\hline \multirow{2}{*}{ Jenis Pemeriksaan } & \multicolumn{9}{c}{ Mikroskopis } \\
\cline { 2 - 8 } & \multicolumn{1}{c}{ Positif } & \multicolumn{2}{c}{ Negatif } & \multicolumn{2}{c}{ Total } \\
\cline { 2 - 8 } & \multicolumn{1}{c}{$\mathbf{n}$} & $\mathbf{( \% )}$ & $\mathbf{n}$ & $\mathbf{( \% )}$ & \multicolumn{1}{c}{$\mathbf{~}$} \\
\hline RDT & & & & & \\
Positif & 4 & 22,2 & 0 & 0,0 & 4 & 22,2 \\
Negatif & 0 & 0,0 & 14 & 77,6 & 14 & 77,8 \\
\hline
\end{tabular}

Sumber : Data Primer, 2020

Tabel 5. Perbandingan Hasil Pemeriksaan RDT dengan Mikroskopis Per Subjek

\begin{tabular}{|c|c|c|c|c|c|c|}
\hline \multirow{2}{*}{ No } & \multirow{2}{*}{$\begin{array}{c}\text { No } \\
\text { Sampel }\end{array}$} & \multirow{2}{*}{$\begin{array}{l}\text { Pemeriksaan } \\
\text { Mikroskopik }\end{array}$} & \multicolumn{2}{|c|}{ Pemeriksaan RDT } & \multirow[b]{2}{*}{ P. Mix } & \multirow{2}{*}{ Keterangan } \\
\hline & & & P.Vivax & P. Falciparum & & \\
\hline 1 & 01 & Positif Vivax $(++)$ & + & - & - & True Positive \\
\hline 2 & 02 & Negatif & - & - & - & True Negative \\
\hline 3 & 03 & Negatif & - & - & - & True Negative \\
\hline 4 & 04 & $\begin{array}{l}\text { Positif } \\
\text { Falciparum } \\
(++++)\end{array}$ & - & - & + & True Positive \\
\hline 5 & 05 & Negatif & - & - & - & True Negative \\
\hline 6 & 06 & Negatif & - & - & - & True Negative \\
\hline 7 & 07 & Negatif & - & - & - & True Negative \\
\hline 8 & 08 & Negatif & - & - & - & True Negative \\
\hline 9 & 09 & Negatif & - & - & - & True Negative \\
\hline 10 & 10 & Negatif & - & - & - & True Negative \\
\hline 11 & 11 & $\begin{array}{l}\text { Positif } \\
\text { Falciparum } \\
(++++)\end{array}$ & - & - & + & True Positive \\
\hline 12 & 14 & Negatif & - & - & - & True Negative \\
\hline 13 & 15 & Negatif & - & - & - & True Negative \\
\hline 14 & 16 & Negatif & - & - & - & True Negative \\
\hline 15 & 17 & Negatif & - & - & - & True Negative \\
\hline 16 & 18 & $\begin{array}{l}\text { Positif } \\
\text { Falciparum (+) }\end{array}$ & - & + & - & True Positive \\
\hline 17 & 19 & Negatif & - & - & - & True Negative \\
\hline 18 & 20 & Negatif & - & - & - & True Negative \\
\hline 19 & 12 & Negatif & - & - & - & $\begin{array}{c}\text { RDT Invalid } \\
\text { (dieksklusi) }\end{array}$ \\
\hline
\end{tabular}

Sumber : Data Primer, 2020 
Tabel 6. Spesifisitas dan Sensitivitas RDT

\begin{tabular}{|c|c|c|c|}
\hline \multirow{2}{*}{ RDT } & \multicolumn{2}{|c|}{ Mikroskopik } & \multirow{2}{*}{ Sensitivitas dan Spesifisitas } \\
\hline & Positive & Negative & \\
\hline Positive & $\begin{array}{c}\text { True Positive } \\
4\end{array}$ & $\begin{array}{c}\text { False Positive } \\
0\end{array}$ & $\begin{array}{c}\text { Sensitivity }=\text { TP } /(\text { TP+FN }) \times 100 \% \\
=4 /(4+0) \times 100 \% \\
=100 \%\end{array}$ \\
\hline Negative & $\begin{array}{c}\text { False Negative } \\
0\end{array}$ & $\begin{array}{c}\text { True Negative } \\
14\end{array}$ & $\begin{array}{c}\text { Spesificity }=\text { TN(TN+FP)x100\% } \\
=14 /(14+0) \times 100 \% \\
=100 \%\end{array}$ \\
\hline
\end{tabular}

Sumber: Data Primer, 2020

Tabel 7. Akurasi Spesies (Beda Baca RDT dan Mikroskopis)

\begin{tabular}{cccc}
\hline \multirow{2}{*}{ RDT } & \multicolumn{3}{c}{ Mikroskopik } \\
\cline { 2 - 4 } & Pos PV & Pos PF & Pos Mix \\
\hline Pos PAN (Vivax) & $1(25 \%)$ & - & - \\
\hline Pos PF & - & $1(25 \%)$ & - \\
\hline Pos Mix & - & $2(50 \%)$ & - \\
\hline
\end{tabular}

Sumber: Data Primer, 2020

\section{PEMBAHASAN}

Puskesmas Harapan adalah salah satu dari 19 Puskesmas yang berada dalam wilayah kerja Dinas Kesehatan Kabupaten Jayapura. Jumlah kasus pada tahun 2018 di Puskesmas Harapan sebanyak 1722 dari 8522 penduduk atau nilai API sebesar $202,06 \%$.

Berdasarkan hasil survei, ditemukan bahwa RDT malaria yang digunakan di Puskesmas Harapan Kabupaten Jayapura masih memiliki efektifitas tinggi. Nilai sensitivitas dan spesifisitas yang tinggi mengartikan bahwa alat uji diagnostik cepat (RDT) yang digunakan dapat menemukan kasus positif dan kasus negatif secara tepat. Hal ini sejalan dengan hasil penelitian Rakhman M.A, et al yang dilakukan di Kecamatan Jaro Kabupaten Tabalong Provinsi Kalimantan Timur pada tahun 2012, dengan nilai sensitivitas dan spesifisitas yang tinggi yaitu 98\% sensitivitas dan 100\% spesifisitas. Beberapa penelitian serupa yang dicatat dalam tulisan Rakhman M.A, et al mengungkapkan tentang hasil pemeriksaan dengan RDT yang berbeda-beda baik nilai sensitivitas dan spesifisitasnya. Dikatakan bahwa ada 2 jenis RDT malaria dengan target protein yang berbeda yaitu Histidine Rich Protein 2 (HRP-2) dan Parasite Lactate Dehydrogenase ( $p-L D H)$. RDT dengan target protein HRP-2 dikatakan hanya dapat menemukan adanya infeksi khusus Plasmodium Falciparum, dan tidak dapat mendeteksi adanya plasmodium jenis lain. HRP-2 merupakan protein yang dapat larut dalam air, yang dihasilkan oleh Plasmodium Falciparum pada fase aseksual dan gametosit. RDT dengan target protein $H R D-2$ ini, dapat menyebabkan kejadian negatif palsu, karena tidak akan menemukan infeksi plasmodium lain, sehingga apabila terdapat positif infeksi Plasmodium Vivax dan lainnya, akan dinyatakan 
negatif. Sedangkan target protein p-LDH merupakan enzim glikolitik pada Plasmodium sp, yang dihasilkan pada fase seksual dan aseksual plasmodium. ${ }^{8}$

Penelitian oleh Ritung N, et al yang dilakukan di Likupang Barat Provinsi Sulawesi Utara pada tahun 2015, yang menyatakan bahwa efektifitas RDT masih cukup baik, walaupun dengan nilai sensitivitas yang berbeda yaitu sensitivitas $67 \%$, dan spesifisitas $97 \% .{ }^{9}$ Hasil yang berbeda ini dapat disebabkan karena jumlah sampel yang berbeda, serta keterampilan petugas yang berbeda baik dalam penggunaan RDT, maupun pembacaan slide mikroskop.

Pada penelitian serupa oleh Siahaan L tahun 2011 yang dilakukan di Kabupaten Nias Selatan dan Kotamadya Sabang, Sumatera Utara, ditemukan hasil yang hampir sama dengan Ritung et al, yaitu dengan nilai sensitivitas $63,8 \%$ dan nilai spesifisitas 100\%. Dikatakan oleh Siahaan L, bahwa sensitivitas RDT dipengaruhi oleh kepadatan parasit. Pada kepadatan parasit yang rendah (<500 parasit/ $\mu$ l), sensitivitas RDT menjadi berkurang. Pada penelitiaan Siahaan, tidak ditemukan adanya false positive. Disebutkan Siahaan, alat RDT harus diuji secara berkala, agar diketahui nilai sensitivitas dan spesifisitasnya. Deteksi dini pada penurunan nilai spesifisitas pada RDT dapat mengurangi terjadinya false negatif, khususnya di daerah endemis malaria. ${ }^{10}$

Penelitian oleh Makiah.H pada tahun 2017 yang dilakukan di Puskesmas Sambaliung, menguji perbedaan antara pemeriksaan malaria dengan metode RDT dan Mikroskopis, menemukan bahwa terdapat perbedaan efektifitas antara RDT dan Mikroskopis ( $p$ value Fisher exact $=0,001)$. Dikatakan oleh Makiah, bahwa tes malaria dengan metode RDT tidak dapat menggantikan uji mikroskopis sebagai gold standard pemeriksaan malaria. ${ }^{11}$

Pada penelitian/survei ini justru didapati bahwa kepadatan parasit yang tinggi $(++++)$ pada pembacaan mikroskop, akan terbaca sebagai infeksi Plasmodium Mix oleh RDT. Kepadatan parasite ++++ berarti ada $>10$ parasit dalam 1 lapang pandang sediaan darah tebal. ${ }^{12}$ Perbedaan akurasi spesies pada RDT ini masih dapat diatasi dengan ketelitian laboran dalam mengamati jenis spesies pada slide sediaan darah.

Keterbatasan survei ini terletak pada jumlah sampel yang sedikit, serta waktu dan dana yang sangat terbatas, yang dapat mempengaruhi interpretasi hasil survei.

\section{KESIMPULAN DAN SARAN}

Hasil survei ini menunjukkan bahwa Uji Cepat Diagnostik (RDT) yang digunakan di Puskesmas Harapan masih efektif untuk digunakan sebagai alat diagnostik malaria yang dapat mendeteksi secara cepat dan akurat, terutama di daerah endemis tinggi seperti Papua. Saran untuk Dinas Kesehatan Kabupaten Jayapura agar dapat meningkatkan kualitas SDM laboratorium dalam memeriksa spesimen malaria baik dengan menggunakan RDT maupun slide mikroskop dengan melakukan pelatihan secara berkala. Penelitian atau survei seperti ini perlu dilakukan secara berkala, baik oleh peneliti, maupun pihak pengelola program malaria di Dinas Kesehatan Kabupaten Jayapura, untuk 
mengantisipasi peningkatan kejadian positif palsu maupun negatif palsu.

\section{UCAPAN TERIMA KASIH}

Ucapan terima kasih disampaikan kepada 1) BTKLPP Kelas II Ambon sebagai tempat pengabdian saya yang mendukung terlaksananya kegiatan ini, 2) Dinas Kesehatan Provinsi Papua dan Dinas Kesehatan Kabupaten Jayapura yang telah mengijinkan kegiatan ini terlaksana di wilayah kerjanya, 3) Para profesional yang memberikan kontribusi dalam penyusunan laporan.

\section{DAFTAR PUSTAKA}

1. Fitriany J, Sabiq A. Malaria. Averrous. 2018;4(2):1-20.

2. Kementerian Kesehatan RI. Profil Kesehatan Indonesia 2019 [Internet]. Jakarta:

Kementerian Kesehatan RI; 2020. Available from: http://www.kemkes.co.id

3. Kementerian Kesehatan RI. Situasi Terkini Perkembangan Program Pengendalian Malaria di Indonesia Tahun 2018. Kementerian Kesehatan RI;

4. Dinas Kesehatan Kabupaten Jayapura. Data Malaria Kabupaten Jayapura Tahun 20162018. 2019.

5. Dinas Kesehatan Provinsi Papua. Profil Kesehatan Provinsi Papua Tahun 2019 [Internet]. Kabupaten Jayapura: Dinas Kesehatan Provinsi Papua; [cited 2021 Jun 6]. Available from: https://dinkes.papua.go.id/informasipublik/informasi-berkala/
6. Wilayah-wilayah Endemis Malaria Tinggi di Indonesia | Malaria.id [Internet]. [cited 2021 Apr 29]. Available from: https://www.malaria.id/artikel/wilayahwilayah-endemis-malaria-tinggi-di-indonesia

7. Laporan Mikroskopis Fasyankes Provinsi Papua Tahun 2020. e-SISMAL Subdit Malaria Dirjen Pencegahan dan Pengendalian Penyakit Kemenkes RI;

8. Rakhman MA, Istiana, Al Audhah N. Perbandingan Efektifitas Rapid Diagnostic Test (RDT) Dengan Pemeriksaan Mikroskop Pada Penderita Malaria Klinis. Berkala Kedokteran. 9(1).

9. Ritung N, Pijoh VD, Bernadus JBB. Perbandingan Efektifitas Rapid Diagnostic Test (RDT) dengan oemeriksaan Mikroskop pada Penderita Malaria Klinis di Puskesmas Mubune Kecamatan Likupang Barat. e-Bm. 2018 Jul;6(2):84-9.

10. Siahaan L. Perbandingan Rapid Diagnostic Test dan Pemeriksaan Mikroskopik pada Diagnosis Malaria. Kesmas: National Public Health Journal. 2011 Jun 1;5(6):250.

11. Makiah H. Perbedaan Efektifitas Metode Mikroskopis dan Metode Rapid Diagnostic Test Terhadap Penegakan Diagnosis Malaria di Puskesmas Sambaliung. Mahakam Medical Laboratory Technology Journal. 2017 Nov;11(2):91-103.

12. Kementerian Kesehatan RI. Pedoman Teknis Pemeriksaan Parasit Malaria [Internet]. 2017. Available from: https://www.slideshare.net/hersu12345/bukupedoman-teknis-pemeriksaan-parasit-malaria 